DOI: $10.53469 /$ jissr.2021.08(09).08

\title{
Decriminalisation of Cannabis
}

\author{
Chinki Verma \\ BA, LLB (hons) from Rajiv Gandhi National University of Law, Patiala, LLM from National University of Law, Delhi, India \\ chinki.verma88@gmail.com
}

\begin{abstract}
The article intends to examine, with the help of doctrinal method, the utility of India's strict penal policies against cannabis in the light of various contemporary issues. India Criminalized cannabis under Narcotic Drugs and Psychotropic Substances Act, 1985 pursuant it's international commitment as a signatory to three United Nation's drug conventions. The primary objective behind criminalization was to reduce the incidences of drug abuse. But the experience from the past few decades has been that such law is producing more harm than it actually prevents. Criminalization of cannabis not only violates individual's right to autonomy and self determination but also creates numerous other issues like increasing the incidences of incarceration, economic stress on the legal system, hindrance to medical research, etc.
\end{abstract}

Keywords: cannabis legalisation, cannabis decriminalisation, cannabis consumption, freedom vis a vis paternalism

\section{Introduction}

World Health Organization: "Countries should work toward developing policies and laws that decriminalize injection and other use of drugs and, thereby, reduce incarceration. Countries should work toward developing policies and laws that decriminalize the use of clean needles and syringes.... Countries should ban compulsory treatment for people who use and/or inject drugs" [1]

The article intends to examine, with the help of doctrinal method, the utility of India's strict penal policies against cannabis in the light of various contemporary issues. India Criminalized cannabis under Narcotic Drugs and Psychotropic Substances Act, 1985 pursuant it's international commitment as a signatory to three United Nation's drug conventions. The primary objective behind criminalization was to reduce the incidences of drug abuse. But the experience from the past few decades has been that the such law is producing more harm than it actually prevents. Criminalization of cannabis not only violates individual's right to autonomy and self determination but also creates numerous other issues like increasing the incidences of incarceration, economic stress on the legal system, hindrance to medical research, etc.

According to 2019 NCRB statistics, the SLL crimes under which most number of arrests were made are Liquor \& Narcotic Drugs Related Acts. Out of 210076 total number of arrests made under SLL crimes, 918743 were made only under Liquor \& Narcotic Drugs Related Acts and Out of this about $38.7 \%$ were of person in the age group of 18 to 30 , and most of them were for minor cannabis use only [2]. Thus, the present study indents to examine the possibility of legalization of cannabis for medical use and its decriminalization for non-medical use. The study will undertake a cost benefit analysis of the criminalization of cannabis to establish equilibrium between individual's right to liberty and state interest in cannabis criminalization.

\section{What does the vedas says?}

$$
\begin{aligned}
& \text { पज्च राज्यानि वीरुधां सोमश्रेष्षानि ब्रूमः। } \\
& \text { दर्भो भड़ो यवः सह ते नो मुज्चन्त् अंहसः }
\end{aligned}
$$

-Atharva Veda samhita book 11, Hymn 6, Verse15
The atharva veda, also called the veda of magical portions, talks about five plants(Soma, darbhti, hemp, barley, sdha) as plants with divine qualities. These plants are referred as plants with "golden nectar" and spiritual power. Atharva veda regards cannabis(hemp) as sacred plant and calls its leaves as "guardian angel", these leaves were thrown in spiritual fire(Yagna) to defeat evil powers and bring purity. [3] Numerous Hindu religious tales portray bhang as the dearest drink of the lord Shiva. On many festivals like Shivratri, Holi, etc, consumption of bhang is considered sacred and bhang is also one of the chief ingredient of the offerings made lord shiva. Dhanvantari Nighantu, Sarngandhara Samhita and Kayyadeva Nighantuhe are some significant historic scriptures that also talk about cannabis [4]. Because of this significant position that Cannabis occupy in Indian culture, India's National Policy on Narcotic Drugs and Psychotropic Substances though otherwise condemning drug consumptions stringently, under point 21 specifically legalize consumption of bhang on some festivals.

\section{US Influence and Racial Considerations}

Criminalisation of cannabis at an international level is primarily a consequence of the 1961 Single Convention on Narcotic Drugs. The 1961 convention is the major "event" as an outcome of which cannabis was strictly criminalized globally. Western industrialized nations leaded by United States, were the key group that pushed for rigid drug controls in the UN Conference on Narcotic Drug, and thus the resultant strict drug measures in 1961 conference is often imputed to their efforts. Now to understand as to why actually US advocated for such measures, a reference has to be made to US historical record of its criminalization.

US so called "War on Drug" was based on racial considerations. Drug smoking was seen as a trait common to "Mexicans, African Americans, Latinos, and other racial minorities" [5], who employ these drugs to intoxicate white women and morally degrade them. [6] To specifically quote President Nixon on "war on drug", "There are 100,000 total marijuana smokers in the U.S., and most are Negroes, Hispanics, Filipinos and entertainers. Their Satanic music, jazz and swing result from marijuana use. This marijuana causes white women to seek sexual relations with Negroes, entertainers and any others. ...Reefer makes darkies think they're as good as white men". [7] This argument was not 
only racist and devoid of any rational basis but also derogating to women. Women were seen to be "foolish"; lacking intellect to make their own rational choices thus extremely prone to external influences. As the human rights jurisprudence developed all round the world, these racial justification for cannabis criminalization was challenged, and gradually many states of US decriminalized it. Now if US, who was the key reason for global criminalization of cannabis, has itself decriminalized it; should India, a nation were cannabis has historical importance and was regarded as a part of heritage, is justified in still having such rigid position against its decriminalization?

\section{Indian Legal Policy on Cannabis}

Before proceeding to a discussion about the problems or issues with India's policy regarding cannabis, there is a need to have a basic understanding of India's present cannabis policy. Section 20 of the Narcotic Drugs and Psychotropic Substances Act (1985) enacted by India under its obligation as a signatory to three of United Nation's drug conventions, [Single Convention on Narcotic drugs (1961), Convention on Psychotropic Substances (1971), Convention against Illicit trafficking Narcotic Drugs and Psychotropic substances(1988)] criminalizes cultivation, manufacture, sell, purchase, possession, etc of cannabis. Central Bureau of Narcotics' National Policy on Drug provides that unlike opium poppy, no license could given for legal cultivation of cannabis. Only wild growth of cannabis is allowed. Though the policy provides that even this wild growth should not be misused and use of bud and raisin part of the cannabis plant is strictly prohibited, but the question arises is that, are these directions are actually efficient? How can one assume that people will not misuse the unaccounted wild growth? Wouldn't it be better to have legal licensed growth so it's it has better accounted for?

Cannabis Criminalization: Does it produces more harm than it prevents?

Criminalising cannabis creates following problems:

1) Economic stress on the criminal justice system: According to 2019 NCRB statistics, out of 210076 arrests made under SLL crimes, 918743 were only under Liquor \& Narcotic Drugs Related Acts and out of these most were only for minor drug abuse. A huge amount of state expenditure is made for maintenance of person. Decriminalising minor drug abuse will significantly reduce the economic stress on the state, will also reduce stain on already overburdened courts, and short-staffed police force.

2) Redirecting revenue: The revenue applied for incarceration can be utilised for treatment/rehabilitation of abusers. Huge amount of revenue is used for prosecution and incarnation of accused. If instead of criminal penalties, civil penalties are imposed, the revenue saved could be applied for treatment and rehabilitation of abuser. This will contribute significantly in improving public health.

3) Criminal Record: According to 2019 NCRB statistics, out of total number of convictions under Liquor \& Narcotic Drugs Related Acts about 38.7\% were of person in the age group of 18 to 30 use. Past criminal record creates various issues for a person, it effects a person's employment opportunity, social credit, etc.
There ills that criminal record brings is detrimental to the future of the individual as well as his family [8].

4) Marginalised effected more: Criminalisation of cannabis mostly victimises marginalised with not much impact on rate of drug abuse.. Rich are able to go scot free by employing best legal practitioners, it is the poor who are convicted and sentenced. As a result of which, not only the abuser but his family suffers.

5) Better quality drugs: decriminalisation of cannabis will increase access to better quality cannabis, and also the production and supply would come under government regulation. The present policy of wild growth of cannabis without licensing it, leads to trafficking and mixing of drugs with other cheaper drugs.

\section{Legalisation or Decriminalisation?}

Though often used interchangeably, the words "legalization" and "decriminalization" have distinct meanings. Legalization is making an act/thing permissible by law, thus doing the act would not attract any penalties, be it criminal or civil. Decriminalization on the other hand means removal of criminal penalties on a particular act/thing, that is, doing the act would not attract criminal penalties. However, it should be noted that this does not mean that civil penalties could not be imposed.

\section{Should cannabis be legalized or decriminalized?}

\section{Medical Use}

In India, even medical use of cannabis is prohibited. NDPS act prohibits a doctor from prescribing cannabis and also pose a impediment to research on it to discover other possible medical use of it. But denying access for medical use, when there is global evidence of its therapeutic use justified? What's the opinion of medical community on it?

The medical community has for decades emphasized on its important medicinal valve for specific medical conditions like anorexia, glaucoma, cancer, cachexia, etc. Bertha K. Madras, Professor of Psychobiology, Harvard Medical School, advance that "whole plant cannabis can be used for multiple therapeutic purposes" [9]. She states that cannabis alleviate pain, seizure disorders, enhance appetite, and relieve a myriad of other neurological or metabolic diseases thus in the light of various factors like inadequacies in current medications to treat specific symptoms or diseases, along with self-reported benefits derived from cannabis [10] cannabis should be legalised atleast for medical use. A research conducted by the All India Institutes of Medical Sciences in 2019 also concluded that medical uses of cannabis could not be ignored [11]. It should be noted that due to this global evidence of medical and therapeutic uses of cannabis, United Nations Commission for Narcotic Drugs on 2th December, 2020, on the basis of a proposal moved by World Health Organisation in 2019, has voted to remove cannabis for medicinal purposes from schedule IV drug and placed in schedule I. The decision for such reclassification was passed by 27 to 25 votes, where even India voted in favour of it. [12] Thus, the researcher advocates for legalisation of medical cannabis. 


\section{Non-medical Use}

Unlike medical cannabis, the researcher does not advocate for legalization of cannabis for non-medical use. However, decriminalization of non-medical use of cannabis is advised on the ground of the various issues discussed under point 3.2 .

Decriminalization of non-medical cannabis would mean that trade, supply, cultivation etc of cannabis would still be prohibited, any cannabis recovered will still be liable for confiscation, but a person would not be subjected to imprisonment for just for consuming cannabis. This however doesn't mean that civil penalties or community service could not be awarded. The focus here will be on treatment and rehabilitation rather than criminal charge.

\section{Is Cannabis Criminalization a Violation of Individual Liberty?}

According to Human rights Watch, "Subjecting people to criminal sanctions for the personal use of drugs, or for possession of drugs for personal use, infringes on their autonomy and right to privacy" [13]. Personal autonomy simply means the ability to choose freely out of diverse option. This choice is not subject to moral or societal evaluation. J.S.Mill also in his celebrated work. On liberty, emphasised upon individual autonomy and right to selfdetermination. He stated that individual liberty should be given full protection, only case where interference with it could be allowed is when it is causing harm to another individual. Based upon this harm Principle of criminal law was evolved. Harm principle prohibits criminalisation of any act when no harm is caused to another individual. According to him "His own good, either physical or moral, is not a sufficient warrant. Over himself, over his own body and mind, the individual is sovereign (Mill 1906, pp. 12-13). [14] Kant's concept of right to self determination also prohibits any intervention with the personal choices of individual. In 2009, Supreme Court of Argentina in Fallo Arriola case (A. 891. XLIV), held that punishment for personal possession of cannabis is violation of right to privacy and personal autonomy [15]. In Ravin v. State [16], Supreme Court of Alaska held that "the citizens of the State of Alaska have a basic right to privacy in their homes... This right to privacy would encompass the possession and ingestion of substances such as marijuana" [17]. Similarly, various other nations round the world have employed same approach to liberty to support decriminalization of cannabis holding that it as a violation of right to privacy.

\section{Is there A Geneuine State Interest in its Criminalization?}

Legal paternalism approach is the main justification employed for justifying state interest in drug criminalisation. According to this approach, state can legitimately intervene with Individual liberty in order to save him from 'self harm'. That is, state, for 'own good' and 'welfare' of the individual can legitimately use coercion. But, the question is, is making a person subject to criminal sanctions for minor abuse actually in interest of the individual? Drug consumption is criminalised to discourage its abuse and promote public health. But, is sentencing people to prison sentences actually contributing to public health? Will decriminalisation increase the rate of drug abuse? To answer this question a reference has to be made to the experiences of the countries like Portugal, Canada, Netherlands, New Zealand, Peru, Poland, Uruguay etc. that decriminalised/legalised cannabis. Here, Portugal being the first country that decriminalised drug for all purposes, its experience is most relevant. After decriminalisation in 2001, the country experienced a significant reduce in the number of abuse. [18] These successful results led Portugal to further legalise medical cannabis in 2018. Similar has been the experience of the other countries. Decriminalised not also ensured better access to quality drugs but also greater focus of rehabilitation and treatment. Thus, benefits yielded by decriminalisation overweight the benefits of criminalisation. Therefore, drug decriminalisation is more in state interest then its criminalisation.

\section{Can Equilibrium be established between Individual Liberty and State Interest?}

Equilibrium between the two could be best established by legalising cannabis for medical use and decriminalising cannabis for non-medical use. Legalisation of medical cannabis will ensure proper access to cannabis for treatment of specific medical conditions [as discussed in point 3.3.1] and encourage research for discovering other therapeutic uses of it. As a patient right to access medical cannabis cannot be overshadowed by the mere possibility of abuse by others. Simultaneously, decriminalising cannabis for nonmedical purpose would ensure state interest as any cultivation, supply, trade etc of cannabis without state license would still be an offence. Decriminalisation would ensure state power to punish an individual for substance abuse with civil penalties, if not with criminal penalties. At the same time would save individual from incarceration and the evils that a criminal record brings.

\section{Conclusion}

India following a paternalistic approach criminalised cannabis by enacting Narcotic Drugs and Psychotropic Substances Act, 1985, with the objective of promoting public health and reducing substance abuse. But, the experience past the years has been that the approach is yielding contradictory paternalistic results [19]. That is, it does more harm than it prevents. Not only does criminalisation affect people's access to quality drugs thus causing greater harm due to usage of adulterated drug but also subjects people to criminal penalties even for minor abuse. Incarceration results into evils of criminal record that is detrimental to the future of the abuser as well as his family. Maneka Gandhi at a meeting of a group of ministers (GOM), which examined the draft cabinet note National Drug Demand Reduction Policy [20], also recognised these ills of drug criminalisation. Specifically focusing on cannabis, she advocated for its decriminalisation. She stated, "some of the developed countries like the US, marijuana has been legalised which ultimately results in less drug abuse...the possibility of the same maybe explored in India" [21].

Apart of the ills of incarceration, criminalisation of cannabis is also criticised from liberty stand. Criminalisation of 
cannabis is against a individuals' right to autonomy and self determination. A person is being subjected to criminal provisions and penalties for an act, which is causing no harm to other individual. In India even medical cannabis is prohibited, which is contradictory to opinion of medical community. Medical community for decades is advocating for the legalisation of cannabis in the view its part in treatment of certain specific health conditions.

\section{What could be done?}

Thus, based on the discussion made in the earlier chapter, considering the cost benefit analysis of the social, economic and legal issues with cannabis criminalisation the researcher advocates for legalisation of cannabis for medical use and decriminalisation of cannabis for non-medical use. Legalisation of medical cannabis would ensure its availability for treatment of specific medical conditions and encourage further research of its therapeutic values. And decriminalisation of cannabis will save an individual form the evils incarceration at the same time equipt state to punish cannabis abuse with civil penalties.

\section{What should be the plan of action?}

Considering the successful results of cannabis decriminalisation in countries like Portugal, USA etc, India should adopt a short-term cannabis decriminalisation pilot programme and if the program yields favourable results, cannabis could be decriminalised all across the nation. Reference for drafting pilot programme could be taken from the 4 year pilot programmes enacted by Denmark in 2018 and 5 year pilot programme enacted by Ireland. Similarly, India could draft a 4-5 year pilot programme and after the expiry of this period, based on the evaluation of the results a final judgement as to the policy regarding cannabis could be made. If the results are favourable than a final policy could be drafted.

\section{References}

[1] World Health Organization, "Policy Brief: H.I.V. Prevention, Diagnosis, Treatment and Care for Key Populations: Consolidated Guidelines July 2014," WHO/HIV/2014.8.

[2] National Crime Records Bureau, Crime In India 2019, Volume

III, https://ncrb.gov.in/sites/default/files/CII\%202019\%20 Volume\%203.pdf

[3] Sindhu Karpakal, Cannabis - One of the sacred plant in Atharva Veda, LINKEDIN, (Dec. 2, 2020, 10:04 AM) "https://www.linkedin.com/pulse/cannabis-onesacred-plant-atharva-veda-sindhu-karpakal/"

[4] Sameeruddin Shaik, Legalization of Cannabis in India, TIMES OF INDIA (Aug. 29, 2020), https://timesofindia.indiatimes.com/readersblog/samee r/legalization-of-cannabis-in-india-25286/, (Last visited on Dec. 9, 2020).

[5] Matthew J. Routh, Re-Thinking Liberty: Cannabis Prohibition and Substantive DueProcess, 26 KAN. J.L. \& PUB. POL'y 143 (2017).

[6] Idib.

[7] Robert Solomon, Racism and Its Effect on Cannabis
Research, NATIONAL CENTER FOR BIOTECHNOLOGY INFORMATION, (Dec. 8, 2020, 21:04 AM)

https://www.ncbi.nlm.nih.gov/pmc/articles/PMC71736 75/

[8] Neha singhal and Naveed Ahmad, Case for Decriminalising Cannabis Use in India, VIDHI CENTRE FOR LEGAL POLICY, (Dec.8,2020, 19:54 AM) https://vidhilegalpolicy.in/research/case-fordecriminalising-cannabis-use-in-india/

[9] Bertha K. Madras, Update of Cannabis and its medical use, 37th ECDD (2015) Agenda item 6.2.

[10] Ibid.

[11] Sameeruddin Shaik, Legalization of Cannabis in India, TIMES OF INDIA (Aug. 29, 2020), https://timesofindia.indiatimes.com/readersblog/samee r/legalization-of-cannabis-in-india-25286/ (Last visited on Dec. 9, 2020).

[12] Isabella Kwai, U.N. Reclassifies Cannabis as a Less Dangerous Drug, THE NEW YORK TIMES (Dec. 2, 2020),

https://www.nytimes.com/2020/12/02/world/europe/ca nnabis-united-nations-drug-policy.html (Last visited on Dec. 9, 2020).

[13] Human Rights Watch, "Americas: Decriminalize Personal Use of Drugs; Reform Policies to Curb Violence, Abuse"(June 4, 2013 14:40PM), https://www.hrw.org/news/2013/06/04/americasdecriminalize-personal-use-drugs

[14] John Stuart, Mill, ON LIBERTY. London: Longman, Roberts \& Green, 1869.

[15] The Special Committee On Drugs And The Law Of The New York City Bar Association, Charting A Wiser Course: Human Rights And The World Drug Problem,( April 19, 2016), https://www.unodc.org/documents/ungass2016/Contrib utions/Civil/New_York_City_Bar/Final_Charting_A_ Wiser_Course.pdf.

[16] Ravin v. State, 537 P.2d 494, 502 (Alaska 1975).

[17] Ibid.

[18] Glenn Greenwald, Drug Decriminalization In Portugal: Lessons For Creating Fair And Successful Drug Policies, CATO INSTITUTE, (Dec. 11, 2020, 22:04 AM) https://www.cato.org/sites/cato.org/ files/pubs/pdf/greenwald_whitepaper.pdf.

[19] Natasha Treasurywala, Legal Paternalism: The Indian Context, (2005) 4 Law Rev GLC 75

[20] TNN, Make marijuana legal for medical needs: Maneka Gandhi, TIMES OF INDIA (July. 31, 2017), https://timesofindia.indiatimes.com/india/makemarijuana-legal-for-medical-needs-manekagandhi/articleshow/59838664.cms (Last visited on Nov 28, 2020).

[21] Ibid. 